\title{
Relationship between learning habits and socioeconomic status : a COVID-19 pandemic study
}

\author{
Nurulhuda Ghazali", Nurul Hidayah Mat Zain, Siti Feirusz Ahmad Fesol, Nor Aiza Moketar, \\ Edzreena Edza Odzaly and Noor Hasimah Ibrahim Teo \\ Senior Lecturer, Faculty of Computer and Mathematical Sciences, Universiti Teknologi MARA Cawangan Melaka, \\ Kampus Jasin, 77300 Merlimau, Melaka, Malaysia
}

Received: 30-September-2020; Revised: 21-January-2021; Accepted: 24-January-2021

(C)2021 Nurulhuda Ghazali et al. This is an open access article distributed under the Creative Commons Attribution (CC BY) License, which permits unrestricted use, distribution, and reproduction in any medium, provided the original work is properly cited.

\begin{abstract}
The education sector is no exception from the unexpected circumstances due to the spread of COVID-19, which forced for the full implementation of online digital learning or e-learning. Now, e-learning has played a key role to enable the field of teaching and learning to be conducted in the amid of pandemic. However, this new style of learning has affecting the students' manner in studying. Following this, our study aims to identify the changes that occur in the students' habits in regards to their learning methods during the pandemic and to determine and investigate the relationship between socioeconomic status with learning habits. The researchers have conducted a survey among undergraduate students of Faculty of Computer and Mathematical Sciences, Universiti Teknologi MARA, Melaka Branch and received 675 responses. The relationship between the psychological disruption variable with the perception of students regarding the importance to learn by themselves and also motivate themselves affecting their effectiveness during COVID-19 were investigated using Pearson product moment correlation coefficient. The results revealed that there is a small, positive correlation between the variables of psychological disruption impact $(r=0.198)$ and students' necessity of self-learning and self-motivation $(r=0.219)$.
\end{abstract}

\section{Keywords}

COVID-19, Online learning, Students learning habits, Students psychological, Socioeconomic.

\section{Introduction}

Since the sudden closure of most universities around the world due to COVID-19 pandemic, a lot of students and academic staff now need to be working from home. All education sectors apparently need to shut down their operation because in most countries, mass gathering is completely prohibited [1]. This is an effective way to avoid major outbreak of this pandemic. Academic staff currently need to teach online during this pandemic in order to keep the semester going [2].

Online teaching tools have risen abruptly in line with the pandemic outbreak. Academicians and students are using these tools to carry on with their syllabus. The students' learning habits might change due to the need to adapt to these technologies.

*Author for correspondence

102
Academic performance of students mostly relies on their existing knowledge, academicians and their teaching approaches, socioeconomic status, and their own efforts [3].

Students coming from different socioeconomic statuses may have different levels of motivation and factors that contribute to their learning habits [4]. Their learning habits might need some adjustments to comply with the online learning approach as well as being at home during the pandemic. In some situations, students become less active (physically) as they have to spend more screen time thus interrupting their sleep patterns which can result in loss of cardiorespiratory fitness [5]. To ensure the students' performance do not deteriorate, an early intervention is required by determine the factors involved. Early intervention is crucial to avoid unforeseen circumstances such as failing of subjects, low graduate percentage and also a rise in the depression statistics among students. 
This study aims to identify the learning habits in students during COVID-19 pandemic and below are the objectives associated with this study:

- To investigate the variation in their study pattern before and at the time of the pandemic

- To study the relationship between socioeconomic status and students' learning habit during COVID19

- To find the relationship between the psychological disruption variable with the perception of students regarding the importance to learn by themselves and also motivate themselves affecting their effectiveness during COVID-19

The outcome of this study can be used to assist students and academicians as well as parents to recognize the features that might affect the learning habits and learning performance, either positively or negatively. Therefore, this study is hoped to help future students to cope with this pandemic situation more steadily.

\section{Literature review}

\subsection{Students' learning habits}

Students' learning habits involve study skills and study attitude [6]. According to [7, 8] the students' learning habits comprise two key characteristics: carefully deliberating study behaviours and engagement in learning sessions. Most of the previous studies proposed that there is a positive relationship between learning habits and learning performance $[9,10]$. However, some studies $[11,12]$ reported no relationship between these two components.

Besides, based on studies by $[12,13]$, the authors pointed out that one of the critical components in study habits is time spent. Research about time spent was summarized as the more time students participate in study habits, the better their students will get [14]. Nevertheless, a study from [15] reported that the quality of the study was essential when we discuss time spent on studying. Other components that are significantly related to time spent on studying are gender [14], academic interest, parent pressure, school anxiety [15] and motivation [16].

\subsection{Socioeconomic status}

Socioeconomic status (SES) is a measure of an individual's or family's social position relative to others [17]. A study by Ensminger et al. [18] stated there is a positive correlation within three SES indicators: income, occupation, and education. SES involves variables such as parental education and occupational, the income of family $[19,20]$, student's age [21] and home resources [22, 23]. Le et al. [24] reported a correlation between SES and students' reading habits have some impact towards their achievement, academically. that influence academic achievement.

Parental education is one of the essential SES components that can impact students' life since childhood $[25,26]$. A study from Blanden and Gregg [27] found that a household earnings is related to children's education and has a causal impact on educational consequences. A study from Hauser [20] stated that the career of a parent is more crucial that their level of education and salary. They concluded based on the weight of this variable in overall SES. Besides, other factors that contribute to students' success are learning environments [28], accessibility on educational facilities [29, 30] and resources [31, 32].

\section{Methodology}

This study is based on quantitative method. A survey was conducted to investigate undergraduates' learning habits during COVID-19 pandemic. The items in the questionnaire were adapted from [33]. The questionnaire was designed to measure the constructs below:

1. Learning hours taken per day by students based on their demographic data.

2. The relationship between socioeconomic status: gender, year of study, living area and family income with students' learning habit.

\subsection{The participants and procedure}

Participants were recruited from undergraduates of the Faculty of Computer and Mathematical Sciences, Universiti Teknologi MARA, Melaka Branch. The online questionnaire was distributed to all students through their respective academic advisor and the participation was voluntary. The survey was able to gather responses from 675 participants where the majority of the respondents were 18 to 25 years old from five bachelor's degree programmes and one diploma programme in one week. Six participants were excluded from the survey due to their refusal to participate in the survey. Statistical analysis was carried out using the SPSS tool.

\subsection{The instruments}

The survey is divided into three sections. The first section of the survey gathers information about demographic data such as age groups, levels of education, courses studied, semester, total family 
income, and occupation sector for the head of the family. The second section elicits simple information on students' perception of access disruption as well as difficulties experienced due to COVID-19 crisis. The last section identifies students' learning habits which include learning hours, the effectiveness of self-learning, and additional knowledge learnt.

The descriptive analysis was performed on demographic data toward self-learning hours during COVID-19. The descriptive analysis was also performed on data of difficulties experienced using Yes or No closed-ended questions and students' perception of access disruption that utilized a 6-point Likert scale ranging from $1=\mathrm{N} / \mathrm{A}$ or I do not know, $2=$ Much worse than before, $3=$ Worse than before, $4=$ Same as before, $5=$ Better than before, and $6=$ Much better than before.

The association between socioeconomic and learning habits was calculated using Chi-Square Test. Each item of learning habit was analysed based on five categories: less than 2 hours, between 2 to 4 hours, between 4 to 6 hours, between 6 to 8 hours and more than 8 hours. The items are as follow:

- Before COVID-19 crisis, how many hours did you spend per day for self-learning?

- During COVID-19 crisis, how many hours do you spend per day for self-learning?

- Regarding hours of learning during COVID-19 crisis, how many hours are spent on online learning per day?

\subsection{Research design}

To further analyse the research aim and research questions, the primary methods of analysis used were descriptive statistics, Chi-square and Pearson product moment correlation which will be explained in the next part. The Chi-Square Test of Independence is commonly used to test the statistical independence or association between two or more categorical variables, which is suited with this study [34]. It involves two categorical variables which are students' habits on learning amid the COVID-19 and their status of socioeconomic (including gender, year of study, living area, and family income). The hypotheses of the Chi-Square Test can be expressed as below:

- H01: Socioeconomic status: Gender is not associated with students' learning habits.

- H02: Socioeconomic status: Year of study is not associated with students' learning habits.

- H03: Socioeconomic status: Living area is not associated with students' learning habits.

- H04: Socioeconomic status: Family income is not associated with students' learning habits.

Regarding the correlation test, this study is interested in identifying the relationship between the impact of psychological disruption variable with the perception of students regarding the importance to learn by themselves and the factors of self-motivation that promote successful learning for students, as shown in the proposed model below (refer Figure 1).

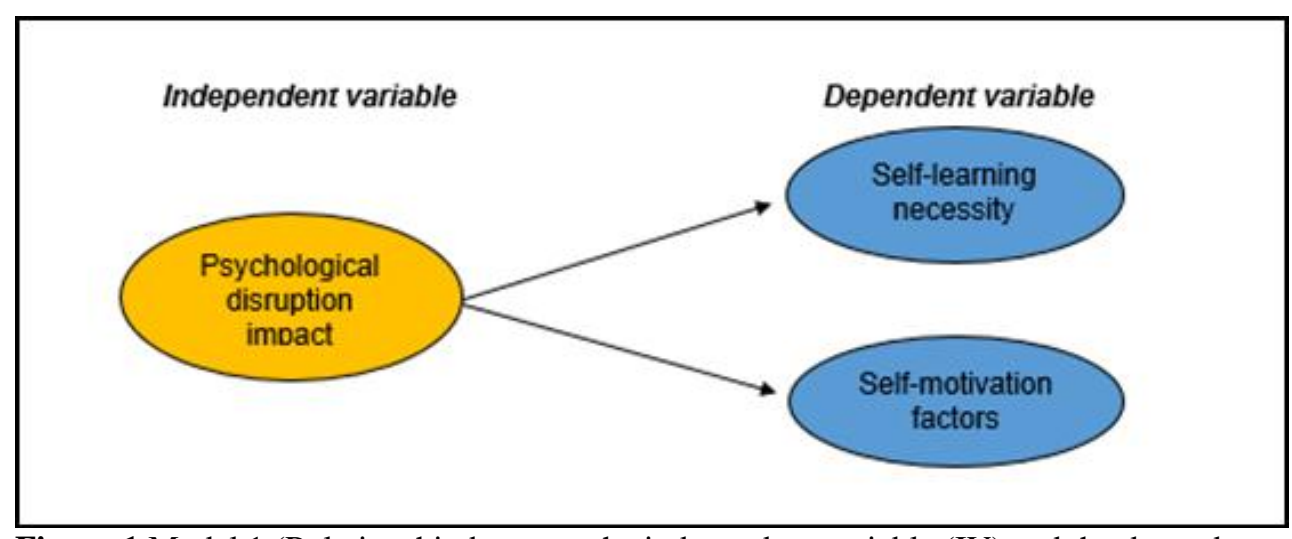

Figure 1 Model 1 (Relationship between the independent variable (IV) and the dependent variables (DV))

\section{Results and analysis}

Table 1 summarizes the demographic information of the respondent groups by online learning hours per day during COVID-19 utilizing a descriptive analysis. Majority of respondents, either male students $56.5 \%$ (169) or female students $65.9 \%$ (243) studied between 4 to 8 daily during COVID-19. While $4.7 \%$ (14) male students and $10.3 \%$ (38) female students were have to studied more than 8 hours per day during COVID-19 pandemic in order 
to catch-up with the learning process. While remaining $38.8 \%$ (116) male students and $23.8 \%$ (88) female students were studied less than 4 hours daily during COVID-19.

With regards to the years of study, majority of the junior students (as much as 65.4\%), which were the 1 st year and 2 nd year students, spent around 4 to 8 hours daily for their online learning during COVID19 compared to the senior students (only around $54.7 \%$ ). As much as $8.5 \%$ among the junior students must studied more than 8 hours daily for their online learning during COVID-19 to sustain with the current learning process. With the different of $12.7 \%$ between the junior and the senior students, a smaller number of junior students were studied less than 4 hours daily for their online learning during COVID19 compared to the senior students.

In the context of level of study, majority of the diploma (as much as 61.5\%) and degree (as much as $61.8 \%$ ) students were studied between 4 to 8 daily during COVID-19. Whereas $27.5 \%$ of diploma students and $32.5 \%$ of degree students were studied less than 4 hours daily during COVID-19. With the remaining of $10.9 \%$ of diploma students and $5.7 \%$ of degree students were have to studied more than 8 hours per day during COVID-19 pandemic.

Regarding the occupation sector of the student's head of family, majority of the students either their parent works in government, private, self-employed, unemployed or from other types of occupation, spent around 4 to 8 hours daily for their online learning during COVID-19. Only $6.1 \%$ and $6.7 \%$ of the students whose parent works in government and private sectors respectively, must spent more than 8 hours daily just to maintain their learning pace, as compared to $13.7 \%$ of students from the selfemployed category.

About $30.9 \%$ (107) of the students from the total family income less than RM4,000 per month (B40) studied less than 4 hours per day, whereas $10.4 \%$ (36) of them studied more than 8 hours per day. Only $7.4 \%$ of the students who lived in urban areas spent more than 8 hours daily and mostly $61.3 \%$ (241) of them spent between 4 to 8 hours daily to study. In overall, the survey revealed that around $30.5 \%$ (204) of the students studied less than 4 hours daily during COVID-19. About $61.7 \%$ (412) of the students studied between 4 hours to 8 hours daily. While remaining $7.8 \%$ (52) of the students studied more than 8 hours daily during COVID-19.
Figure 2 shows the students' overall perception regarding the difficulties that they experienced due to COVID-19 crisis. More than half (59.3\%) of the respondents agreed that they experienced difficulties in their living conditions especially due to hostel disclosures. In addition, as much as $63.3 \%$ (424) of the respondents agreed that they experienced difficulties in travelling during the COVID-19 crisis.

As shown in Figure 3 below, a majority of the students expressed that they had the same level of access in terms of the health care, as much as $50.6 \%$ (338), and internet access, as much as $37.6 \%$ (251) during COVID-19. However, in terms of the access towards their ability to continue their tertiary education, ability to have a decent social life and their state of psychological welfare, most of the students ranked it as worse than before and much worse than before with a total of $63.3 \%$ (423), $61.4 \%$ (410), and 58.5\% (391) respectively.

Figure 4 shows the comparison of students learning hours prior to COVID-19 and during COVID-19 pandemic. It can be seen that more than half $(63 \%)$ of students spent less than 4 hours before the COVID-19 lockdown period and the rest (37\%) spent more than 4 hours daily for self-learning. There is a slight difference during the COVID-19 lockdown period whereby students' self-learning hours increased slightly by $3.2 \%$ for those who spent more than 4 hours of their self-learning time. The online self-learning distribution seems to have a wellbalanced data whereby the maximum percentage belongs to 4 to 8 hours online learning time and the rest are distributed between under 4 hours $(30.5 \%)$ and more than 8 hours $(7.8 \%)$. a. 0 cells $(.0 \%)$ have expected count less than 5 . The minimum expected count is $23.28,18.06,21.41$, and 7.78, respectively.

Next is the Chi-square analysis. The explanation is based on a cross tabulation table, with cases classified according to the categories in each different socioeconomic status which are gender, year of study, living area and family income. The assumption testing of chi-square concerning the minimum expected cell frequency classified that all four variables (gender; year of study; residential area; family income) is above the minimum, where all the expected cell sizes are greater than 5, with 23.28, $20.63,21.41$, and 7.78 respectively. Thus, these variables were eligible for Chi-square analysis. The values of the Chi-square test statistics for gender, year of study, living area, and family income are 21.108 , 11.496, 8.895, and 13.894, respectively. While the degrees of freedom (df) for the test is 2,2 , 
4, and 8, respectively. Table 2 summarizes the Chisquare test results for socioeconomic status variables.

The results reported that there were only two socioeconomic status variables (gender and year of study) found to be significant, where the p-value is less than $0.05, \mathrm{p}=0.000 ; 0.003$. While the other two variables (residential area and family income) are not significant. Due to this, this study rejected the null hypotheses $\mathrm{H} 01$ and $\mathrm{H} 02$. In contrast, the null hypotheses $\mathrm{H} 03$ and $\mathrm{H} 04$ are not rejected. Based on the results, this study can state the followings:

- $H_{01}$ : The proportion of male students who practiced different learning habits is significantly different from the proportion of females who practiced different learning habits. There appears to be an association between gender with students' learning habits.

$x^{2}(2, n=668)=21.208, p=0.000$

- $\mathrm{H}_{02}$ : The proportion of junior students who practiced different learning habits is significantly different from the proportion of senior students who practiced different learning habits. There appears to be an association between year of study with students' learning habits.

$x^{2}(2) \geq 11.496, p=0.003$

- $H_{03}$ : The proportion of students who lived in urban areas who practiced different learning habits is not significantly different from the proportion of students who lived in rural areas who practiced different learning habits. There appears to be no association between living area with students' learning habits.

$x^{2}(4) \geq 8.895, p=0.064$

$\bullet H_{04}$ : The proportion of students who came from B40 or M40 group of income who practiced different learning habits is not significantly different from the proportion of students who came from T40 cluster who practiced different learning habits. There appears to be no association between family income with students' learning habits.

$x^{2}(8) \geq 13.895, p=0.085$
The relationship between the psychological disruption variable, as the IV, with perception of students regarding the importance to learn by themselves and also motivate themselves affecting their effectiveness during COVID-19, as the DVs were investigated using Pearson product moment correlation coefficient. Preliminary analyses were performed to ensure no violation of the assumptions of normality, linearity, and homoscedasticity. The correlation results concluded that there was a small, positive correlation between the two variables, where $\mathrm{r}=.198 ; .219, \mathrm{n}=668, \mathrm{p}<.0005$. This can be summarized as:

-With positive psychological impact towards the students' feeling, the better students' perception regarding the importance to learn by themselves amid COVID-19. Students who had a good access towards their health care, internet, study, social life and psychological welfare could maintain their regular learning academic progress and sustain their learning habit. The students also found that self-learning is necessary and important as per advice from their lecturers, parents, siblings, and friends.

-With positive psychological impact towards the students' feeling is associated with a high level of self-motivation criteria that assists in the students' effective learning during COVID-19. Students who had a good access towards their health care, internet, study, social life and psychological welfare could help to increase the level of their intrinsic motivation; good self-motivation, high concentration skill and able to set daily learning objective; and their extrinsic motivation; good family support, communicate with friends, proper learning environments and learning resources; to support their effective learning during COVID-19.

Table 3 lists the correlation values between the IV and the DVs. While Figure 5 illustrates the relationship model with correspondent correlation values. 
Table 1 Demographic information of the respondents related with self-learning hours per day during COVID-19

\begin{tabular}{|c|c|c|c|c|c|c|}
\hline & \multicolumn{2}{|c|}{ Less than 4 hours } & \multicolumn{2}{|c|}{ From 4 to 8 hours } & \multicolumn{2}{|c|}{ Over 8 hours } \\
\hline & Frequency & Percentage & Frequency & Percentage & Frequency & Percentage \\
\hline \multicolumn{7}{|c|}{ Gender } \\
\hline Male & 116 & 38.8 & 169 & 56.5 & 14 & 4.7 \\
\hline Female & 88 & 23.8 & 243 & 65.9 & 38 & 10.3 \\
\hline \multicolumn{7}{|c|}{ Current year of study } \\
\hline 1 st \& 2nd years & 114 & 26.1 & 285 & 65.4 & 37 & 8.5 \\
\hline 3rd \& 4th years & 90 & 38.8 & 127 & 54.7 & 15 & 6.5 \\
\hline \multicolumn{7}{|c|}{ Level of study } \\
\hline Diploma & 73 & 27.5 & 163 & 61.5 & 29 & 10.9 \\
\hline Degree & 131 & 32.5 & 249 & 61.8 & 23 & 5.7 \\
\hline \multicolumn{7}{|c|}{ Occupation sector of the head of family } \\
\hline Government sector & 62 & 29.2 & 137 & 64.6 & 13 & 6.1 \\
\hline Private sector & 57 & 29.2 & 125 & 64.1 & 13 & 6.7 \\
\hline Self-employed & 45 & 30.8 & 81 & 55.5 & 20 & 13.7 \\
\hline Unemployed & 27 & 38.0 & 42 & 59.2 & 2 & 2.8 \\
\hline Others & 13 & 29.5 & 27 & 61.4 & 4 & 9.1 \\
\hline \multicolumn{7}{|c|}{ Total family income per month (RM) } \\
\hline Less than RM4,000 (B40) & 107 & 30.9 & 203 & 58.7 & 36 & 10.4 \\
\hline $\begin{array}{c}\text { RM4,000 - RM9,000 } \\
\text { (M40) }\end{array}$ & 63 & 28.4 & 149 & 67.1 & 10 & 4.5 \\
\hline $\begin{array}{l}\text { More than RM9,000 } \\
\text { (T40) }\end{array}$ & 34 & 34.0 & 60 & 60.0 & 6 & 6.0 \\
\hline \multicolumn{7}{|c|}{ Residential area } \\
\hline Rural area (Countryside) & 81 & 29.5 & 171 & 62.2 & 23 & 8.4 \\
\hline Urban area (Town/City) & 123 & 31.3 & 241 & 61.3 & 29 & 7.4 \\
\hline
\end{tabular}

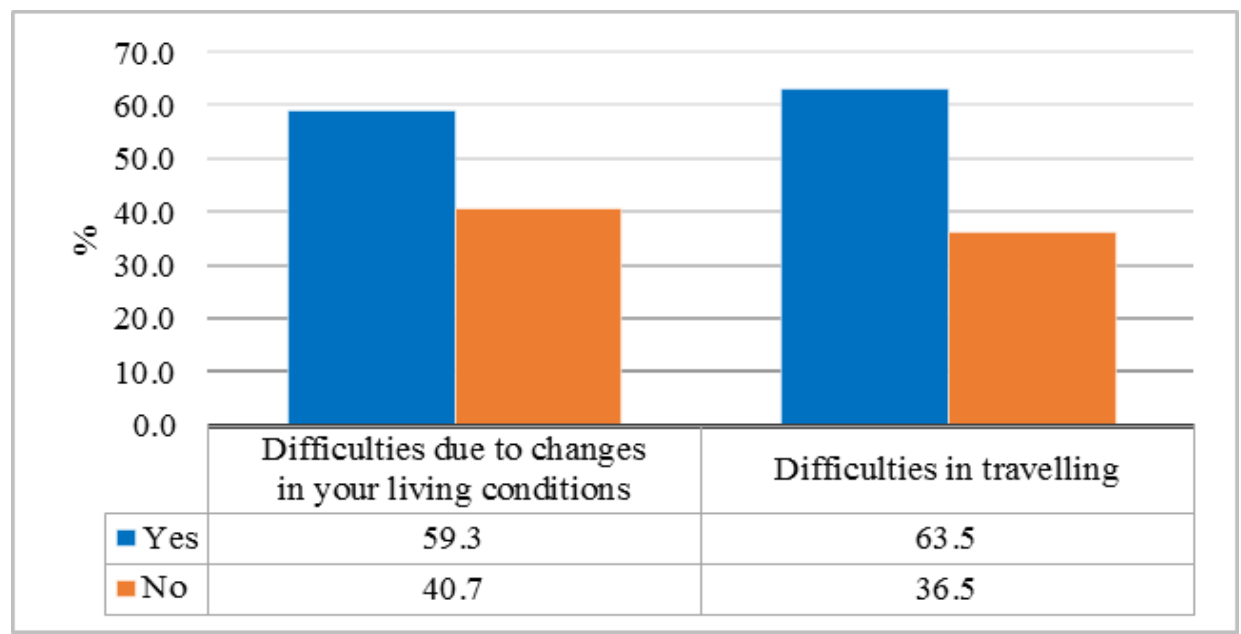

Figure 2 Difficulties experienced during COVID-19 crisis 
Nurulhuda Ghazali et al.

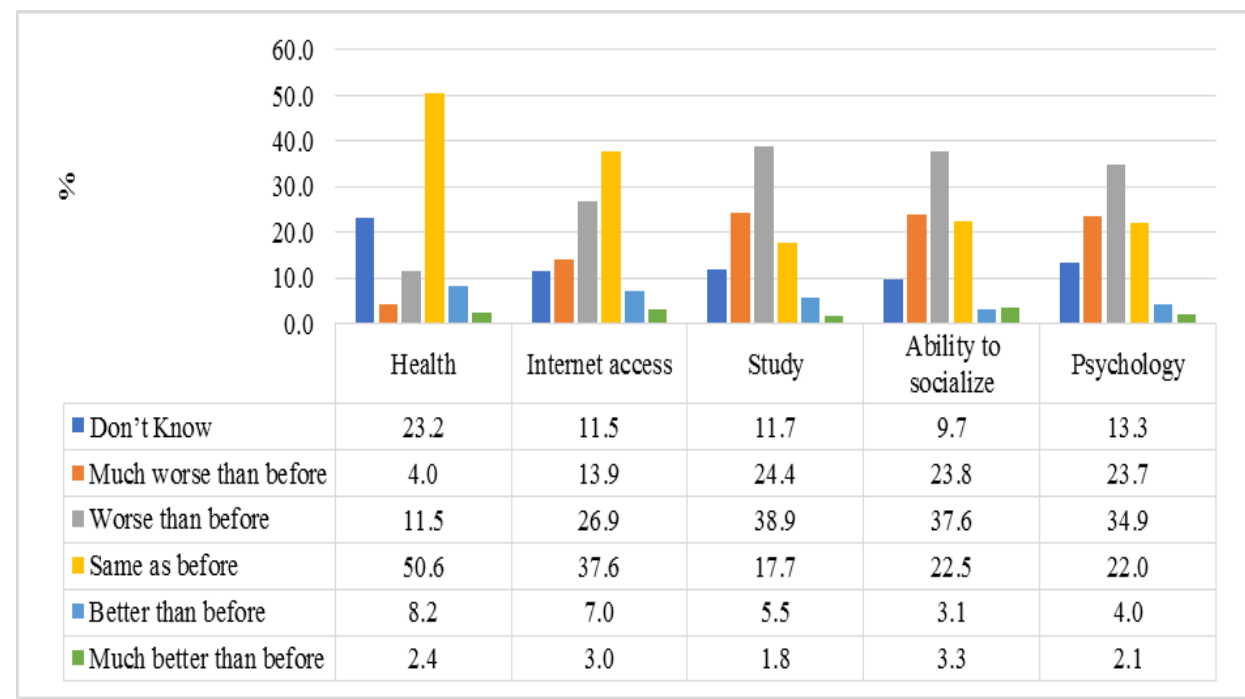

Figure 3 Students' perception of disruption of access due to COVID-19 crisis

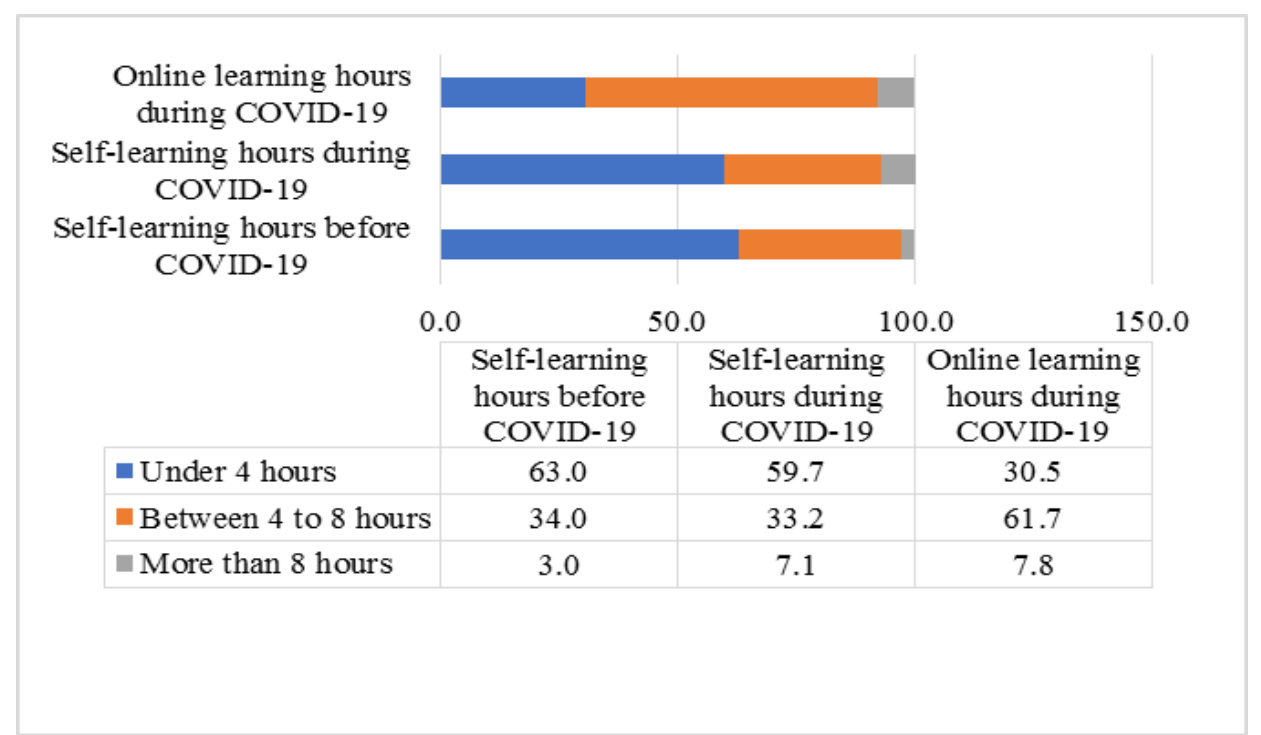

Figure 4 Comparison of students learning hours prior to COVID-19 crisis

Table 2 Chi-square test results for socioeconomic status variable

\begin{tabular}{|c|c|c|c|c|c|c|c|c|}
\hline \multicolumn{9}{|c|}{ Pearson Chi-Square Values } \\
\hline \multirow{2}{*}{$\begin{array}{l}\text { Socioeconomic } \\
\text { status variables }\end{array}$} & \multirow{2}{*}{ Value } & \multirow{2}{*}{ df } & \multicolumn{2}{|c|}{ Significant test } & \multicolumn{2}{|c|}{ Effect size } & \multirow{2}{*}{$\begin{array}{c}\mathbf{N} \text { of } \\
\text { Valid } \\
\text { Cases }\end{array}$} & \multirow{2}{*}{$\begin{array}{l}\text { Hypothesis } \\
\text { result }\end{array}$} \\
\hline & & & p-value & Result & Cramer's V & Result & & \\
\hline $\mathrm{H}_{01}:$ Gender & $21.108^{\mathrm{a}}$ & 2 & 0 & Significant & .178 & Small & 668 & Reject \\
\hline $\begin{array}{l}\mathrm{H}_{02}: \text { Year of } \\
\text { study }\end{array}$ & $11.496^{\mathrm{a}}$ & 2 & 0.003 & Significant & .131 & Small & 668 & Reject \\
\hline $\mathrm{H}_{03}$ : Living area & $8.895^{\mathrm{a}}$ & 4 & 0.064 & $\begin{array}{c}\text { Not } \\
\text { significant }\end{array}$ & .024 & Small & 668 & Not reject \\
\hline $\begin{array}{l}\mathrm{H}_{04} \text { : Family } \\
\text { income }\end{array}$ & $13.894^{\mathrm{a}}$ & 8 & 0.085 & $\begin{array}{c}\text { Not } \\
\text { significant }\end{array}$ & .082 & Small & 668 & Not reject \\
\hline
\end{tabular}


Table 3 Correlation results between psychology disruption impact with self-learning necessity and self-motivation factors

\begin{tabular}{lllll}
\hline DV & Pearson correlation & Sig. (2-tailed) & N & Testing result \\
\hline Self-learning necessity & $.198^{* *}$ & .000 & 668 & Correlate significantly; weak positive \\
\hline Self-motivation factors & $.219^{* *}$ & .000 & 668 & Correlate significantly; weak positive \\
\hline
\end{tabular}

**Correlation is significant at the 0.01 level (2-tailed).

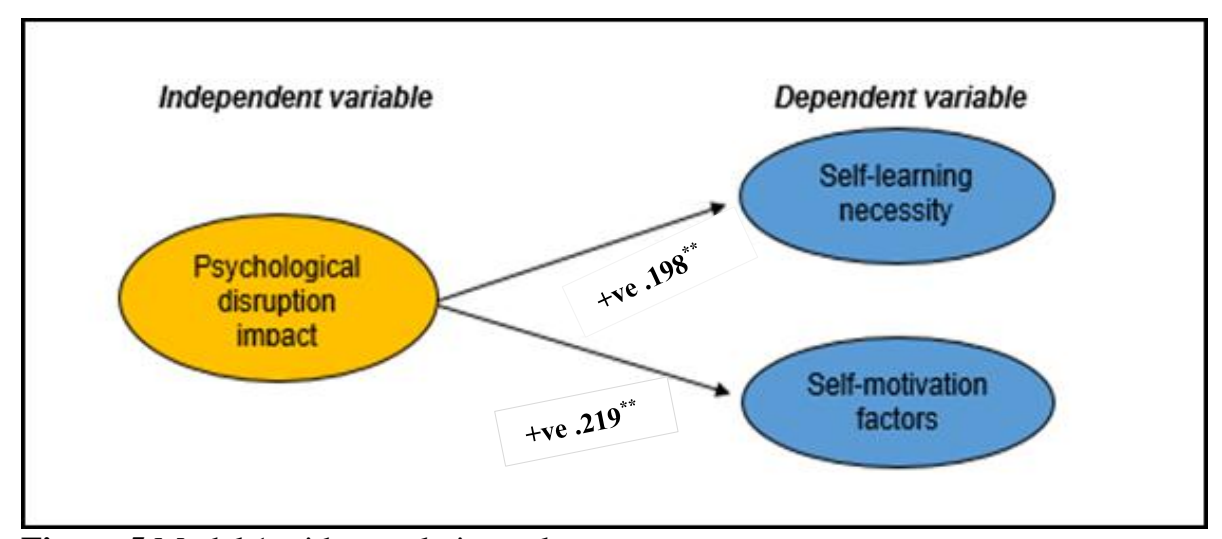

Figure 5 Model 1 with correlation values

\section{Discussion}

The COVID-19 pandemic has caused many schools, colleges, and universities around the world to sudden closures. This severe short-term disruption brings a massive shock not only to the students' social life and learning, but also to their parents and family members [35]. [35] in their study emphasized that this global lockdown of education institutions is going to cause a major interruption in students' learning due to the changes in their learning habits. Due to this, study aims to identify the learning habits in students during COVID-19 pandemic and its mediating factors. The mediating factors that this study interested including the learning duration, variety of socioeconomic status, perception of students regarding the importance to learn by themselves and also motivate themselves affecting their effectiveness. This section discusses further the findings of three (3) research questions corresponding to the mediating factors.

With regards to the first research question, this study is interested to investigate the variation in their study pattern before and at the time of the pandemic as well as time spent by the students to study via online. From the results, we found an increasing pattern in the self-learning duration amid COVID-19 compared to before COVID-19. This result was consistent with the study conducted by [6], who concluded that the students spent more hours (an average of 4.0 hours) daily at home for studying. In our study, a majority of the students spent around 4 to 8 hours, with an average of 6 hours daily to perform their online study. This is supported with a study conducted by [36] which highlighted an interesting finding where a total of 1201 hours were spent per week for online learning activities such as audio streaming (605 hours/ week), video broadcasting (513 hours/ week), desktop screen sharing (78 hours/ week), and meeting online with no video/audio (5 hours/week) during the first week of online class during COVID-19. In addition, [37] suggested in their handbook that using the social media platforms such as Twitter, WhatsApp, Facebook, and Instagram as an online continuous communication medium would assist students in maintaining undisrupted learning in COVID-19 outbreak.

For the second research question, results from Chisquare analysis showed that from four (4) null hypotheses, two null hypotheses, H01: Gender and H02: Year of study were rejected and two null hypotheses, H03: Living area and H04: Family income were not rejected. This reflected that socioeconomic status which referring to gender, either the student is male or female, did bring differences in student's learning pattern amid COVID-19. In addition, this study also found there are differences in student's learning habit with regard to their current year of study, either he/ she was a junior or senior student. This finding is consistent with the study conducted by [6] that able to proof that senior students have a tendency to devote their time for online learning much less compared to younger 
students, as it is reasonable that older students did not need much explanation in understanding the learning activities compared to newer students. Similar findings are portrayed by [38] where younger female students tended to do well with mix of online courses, but older male students are less successful as they took a greater proportion of their courses online.

A valuable insight is that we found no difference in learning habits between the residential area and family income. This indicates that students who lived either in urban or rural areas, did not have differences in their learning habits. This finding is contradicting with a previous empirical study that found there was a significant difference between rural students and urban students in their learning habits [39]. Regarding family income, students who come from different family income backgrounds, either B40, M40, or T40, in the context of Malaysia economic, did not have differences in their learning habits during COVID-19. This finding is also contrary with a study by [6] which discussed that family income had partial influence over students' learning habits. In our sample, it is understandable that during COVID19 , a majority of the students spent an average of 6 hours daily to perform their online learning due to the university closure. Thus, regardless where the students were staying at, either in urban or rural areas and what is their family income level, it shows quite similar learning habits.

For the last research question which is to find the relationship between the psychological disruption variable with the perception of students regarding the importance to learn by themselves and also motivate themselves affecting their effectiveness during COVID-19, a correlation test was conducted. The results revealed that there is a positive relationship between the impact of psychological disruption variable with the perception of students regarding the importance to learn by themselves. Less stress the student's feel, the high the level of importance on students' needs for self-learning especially during this pandemic. The more unstable the student's emotional state, or more stress the students feel, less need for self-learning. Having a good access towards their health care, internet, study, social life and psychological welfare is important in stabilizing the students' emotional state. This can promote supportive advice from lecturers, parents, siblings, and friends on students' necessity of self-learning. This result is concurrent with the study conducted by [40] that highlighted students' feelings, learning supports, family support, and teacher communication valued are key to students' success in online learning environments.

Last but least, this empirical study stated that there is also a positive relationship between the impact of psychological disruption variable and students' selfmotivation towards effective learning. Less stressful the state of the students, more motivated the students would feel, which helps to improve their state of learning during COVID-19. The combination of intrinsic motivation (self-motivation, concentration skill and setting daily learning objective) with extrinsic motivation (family, friends, learning environments and learning resources) is the key to students' success in online learning environments. Tran et al. [6] further explained that learners' intrinsic and extrinsic motivation can help to maintain the learning habits, where the students were willing to spend 40 minutes more studying during school closure. Park and Yun [41] pointed out that providing the correct motivational support is crucial in order to promote different aspects of learning engagement, which towards the end can help in improving their academic achievements.

As for the approach being implemented in this study, there were several limitations that need to be discussed. The factors measured are not broad enough to gain more precise result. Furthermore, the participants even though has a quite number of students but they were all from the same institution. To have a better and accurate research performance, the participants need to consists of several institutions in Malaysia.

\section{Conclusion and future work}

The spread of COVID-19 around the world has significantly disrupted to the education sector. The teaching and learning activities during the pandemic have also moved to the digital environments which involve different tools and platforms to support the activities. These changes have consequently influenced the students' learning habits as they need to adjust with the technologies.

In this paper, we have discussed the mediating factors that influenced the students' learning habits during COVID-19. Among the factors included the learning hours, different socioeconomic statuses, the perception of students regarding the importance to learn by themselves and also motivate themselves affecting their effectiveness. This study is a first step towards a more profound understanding of students' learning habits that might be affecting the learning 
performance. The findings from our study showed there is a significant relationship between socioeconomic statuses and students' learning habits. This provides some insights for better planning and decision making in education sector to face uncertain situations. Our future work has been planned in order to study further on students' learning habits to uncover the factors might influence the students' performance.

\section{Acknowledgment}

The authors would like to acknowledge the support from Research and Industrial Linkages of Universiti Teknologi MARA Melaka through the Internal TEJA Grant for sponsoring the research (File no: GDT2020-33).

\section{Conflicts of interest}

The authors have no conflicts of interest to declare.

\section{References}

[1] Berger ZD, Evans NG, Phelan AL, Silverman RD. Covid-19: control measures must be equitable and inclusive. BMJ. 2020:1-2.

[2] Crawford J, Butler-Henderson K, Rudolph J, Malkawi B, Glowatz M, Burton R, et al. COVID-19: 20 countries' higher education intra-period digital pedagogy responses. Journal of Applied Learning \& Teaching. 2020; 3(1):1-20.

[3] Morales EE. Learning from success: how original research on academic resilience informs what college faculty can do to increase the retention of low socioeconomic status students. International Journal of Higher Education. 2014; 3(3):92-102.

[4] Lam G. A theoretical framework of the relation between socioeconomic status and academic achievement of students. Education. 2014; 134(3):326-31.

[5] Wang G, Zhang Y, Zhao J, Zhang J, Jiang F. Mitigate the effects of home confinement on children during the COVID-19 outbreak. The Lancet. 2020; 395(10228):945-7.

[6] Tran T, Hoang AD, Nguyen YC, Nguyen LC, Ta NT, Pham QH, et al. Toward sustainable learning during school suspension: socioeconomic, occupational aspirations, and learning behavior of Vietnamese students during COVID-19. Sustainability. 2020; 12(10):1-19.

[7] Maiyo J, Siahi EA. Study of the relationship between study habits and academic achievement of students: a case of Spicer higher secondary school, India. International Journal of Educational Administration and Policy Studies. 2015; 7(7):134-41.

[8] Özsoy G, Memiş A, Temur T. Metacognition, study habits and attitudes. International Electronic Journal of Elementary Education. 2009; 2(1):154-66.

[9] Ebele UF, Olofu PA. Study habit and its impact on secondary school students' academic performance in biology in the federal capital territory, Abuja.
Educational Research and Reviews. 2017; 12(10):5838.

[10] Bilge F, Tuzgol Dost M, Cetin B. Factors affecting burnout and school engagement among high school students: study habits, self-efficacy beliefs, and academic success. Educational Sciences: Theory and Practice. 2014; 14(5):1721-7.

[11] Illahi BY, Khandai H. Academic achievements and study habits of college students of district pulwama. Journal of Education and Practice. 2015; 6(31):1-6.

[12] Yu DD. How much do study habits, skills, and attitudes affect student performance in introductory college accounting courses? New Horizons in Education. 2020; 59(3): 1-15.

[13] Nonis SA, Hudson GI. Performance of college students: impact of study time and study habits. Journal of Education for Business. 2010; 85(4):22938.

[14] Kalenkoski CM, Pabilonia SW. Does high school homework increase academic achievement? Education Economics. 2017; 25(1):45-59.

[15] Plant EA, Ericsson KA, Hill L, Asberg K. Why study time does not predict grade point average across college students: implications of deliberate practice for academic performance. Contemporary Educational Psychology. 2005; 30(1):96-116.

[16] Bergin DA. Student goals for out-of-school learning activities. Journal of Adolescent Research. 1989; 4(1):92-109.

[17] Townsend N. Public health mini-guides: obesity ebook. Elsevier Health Sciences; 2014.

[18] Ensminger ME, Fothergill KE, Bornstein MH, Bradley RH. A decade of measuring SES: what it tells us and where to go from here. Socioeconomic Status, Parenting, and Child Development. 2003.

[19] Hauser RM. Measuring socioeconomic status in studies of child development. Child Development. 1994; 65(6):1541-5.

[20] Mueller CW, Parcel TL. Measures of socioeconomic status: alternatives and recommendations. Child Development. 1981; 52(1): 13-30.

[21] Ke F, Kwak D. Online learning across ethnicity and age: a study on learning interaction participation, perception, and learning satisfaction. Computers \& Education. 2013; 61:43-51.

[22] Coleman JS. Social capital in the creation of human capital. American Journal of Sociology. 1988; 94:S95120.

[23] Duncan GJ, Brooks-Gunn J. Income effects across the life span: integration and interpretation. Consequences of Growing up Poor. 1997:596-610.

[24] Le TT, Tran T, Trinh TP, Nguyen CT, Nguyen TP, Vuong TT, et al. Reading habits, socioeconomic conditions, occupational aspiration and academic achievement in Vietnamese junior high school students. Sustainability. 2019; 11(18):1-29.

[25] Tran T, Le TT, Nguyen TT, Pham AG, Vu TH, Nguyen $\mathrm{MH}$, et al. The relationship between birth order, sex, home scholarly culture and youths' reading practices in promoting lifelong learning for sustainable 
Nurulhuda Ghazali et al.

development in Vietnam. Sustainability. 2019;11(16):1-26.

[26] Sirin SR. Socioeconomic status and academic achievement: a meta-analytic review of research. Review of Educational Research. 2005; 75(3):417-53.

[27] Blanden J, Gregg P. Family income and educational attainment: a review of approaches and evidence for Britain. Oxford Review of Economic Policy. 2004; 20(2):245-63.

[28] Henderson AT. The evidence continues to grow: parent involvement improves student achievement. An Annotated Bibliography. National Committee for Citizens in Education Special Report. 1987.

[29] Marks GN, Cresswell J, Ainley J. Explaining socioeconomic inequalities in student achievement: the role of home and school factors. Educational Research and Evaluation. 2006; 12(2):105-28.

[30] McLoyd VC. Socioeconomic disadvantage and child development. American Psychologist. 1998; 53(2):185-204.

[31] Rideout VJ, Foehr UG, Roberts DF. Generation M $^{2}$ : media in the lives of 8 to 18 -year-olds. Henry J. Kaiser Family Foundation. 2010.

[32] Roberts DF. Generation M: media in the lives of 8 to 18 year-olds. Henry J. Kaiser Family Foundation; 2005.

[33] Trung T, Hoang AD, Nguyen TT, Dinh VH, Nguyen YC, Pham HH. Dataset of vietnamese student's learning habits during COVID-19. Data in Brief. 2020; 30:1-7.

[34] Pallant J. SPSS survival manual: a step by step guide to data analysis using IBM SPSS. Routledge. 2020.

[35] Burgess S, Sievertsen HH. Schools, skills, and learning: the impact of COVID-19 on education. VOX. 2020.

[36] Basilaia G, Kvavadze D. Transition to online education in schools during a SARS-CoV-2 coronavirus (COVID-19) pandemic in Georgia. Pedagogical Research. 2020; 5(4):1-9.

[37] Huang RH, Liu DJ, Tlili A, Yang JF, Wang HH. Handbook on facilitating flexible learning during educational disruption: the chinese experience in maintaining undisrupted learning in COVID-19 outbreak. Beijing: Smart Learning Institute of Beijing Normal University. 2020.

[38] Glazier RA, Hamann K, Pollock PH, Wilson BM. Age, gender, and student success: mixing face-to-face and online courses in political science. Journal of Political Science Education. 2020; 16(2):142-57.

[39] Palanisamy S, Arunachalam N. Impact of learning habits and selfesteem on academic performance of higher secondary mathematics students. ParipexIndian Journal of Research. 2019.

[40] Jowsey T, Foster G, Cooper-Ioelu P, Jacobs S. Blended learning via distance in pre-registration nursing education: a scoping review. Nurse Education in Practice. 2020.
[41] Park S, Yun H. The influence of motivational regulation strategies on online students' behavioral, emotional, and cognitive engagement. American Journal of Distance Education. 2018; 32(1):43-56.

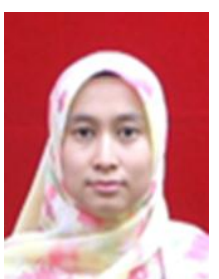

Nurulhuda Ghazali is a lecturer at the Universiti Teknologi MARA for more than 10 years. She received her Bachelor of Science and Master of Science (Computer Science) in 2008 and 2010 respectively at Universiti Teknologi Malaysia. In 2018, she has been awarded by the Malaysian Board of Technologist as Professional Technologist in Information and Computing Technology. Her research interest is mainly focusing on Data Science and Bioinformatics.

Email: nurulhudaghazali@uitm.edu.my

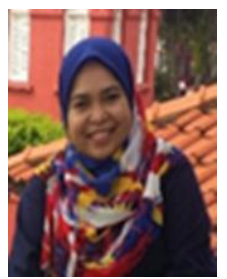

Nurul Hidayah Mat Zain received the Doctor of Philosophy (Visual Informatics) from Universiti Kebangsaan Malaysia (UKM) in 2016. She completed the Bachelor of Computer Science (Software Engineering) and MSc Computer Science (Multimedia System) both from Universiti Putra Malaysia (UPM), Serdang, Malaysia, in 2002 and 2003, respectively. She is currently a Senior Lecturer with the Department of Computer Science (Multimedia Computing), UiTM Cawangan Melaka, Campus Jasin. She published many Scopus and ISI Thomson indexing publications, including journal, proceeding, chapter in books, and articles. She also won several gold medals, diamond awards, and platinum award in research and innovation exhibition. She is also a reviewer paper for national and international journals, including Q1 journals, and actively involved in several grants as project leader and co-researcher. Her research interest is Game Design, Gamification, Serious Game, Game Technology, User Experience, Human-Computer Interaction, and Eye-Tracking.

Email: nuru1417@uitm.edu.my

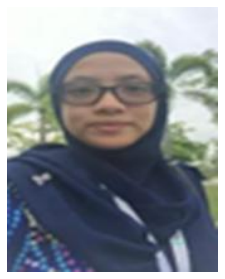

Siti Feirusz Ahmad Fesol is a Senior Lecturer and E-Learning Coordinator at the Universiti Teknologi MARA (UiTM). She holds a PhD in Information and Communication Technology which specialize in online learning and MSc in Database, both from Universiti Teknikal Malaysia Melaka back in year 2014 and 2019. She holds a BSc in Business Information System from Univesiti Teknologi PETRONAS (2010). Her research interest was in Educational Technology, Mobile Learning, Database, Wearable Technology, and MOOC.

Email: feirusz@utm.edu.my 


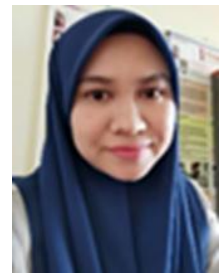

Nor Aiza Moketar is a Senior Lecturer in Faculty of Computer and Mathematical Sciences, University of Technology MARA, Malaysia. She holds a PhD (2018) and MSc (2014) in Software Engineering and Intelligence from UTeM, and BSc in Information Technology from University Malaya (2007). She previously works as a software developer in a multi-national company before commencing as academician. Her research interests are Software Engineering Requirements, Testing and Intelligence.

Email: noraiza1@utm.edu.my

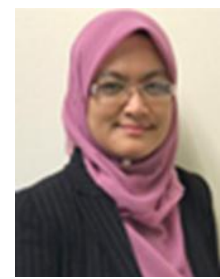

Edzreena Edza Odzaly is a senior lecturer at Universiti Teknologi MARA (UiTM) Melaka, Malaysia. She holds a $\mathrm{PhD}$ in Computer Science from Queen's University Belfast (QUB) United Kingdom in 2014. She obtained her Master degree in MSc. Real-time Software Engineering from Universiti Teknologi Malaysia (UTM) in 2005 and her first degree from International Islamic University Malaysia (IIUM) in Management Information System (2002). In addition to her academic background, she also had multiple recent achievement in professional recognitions. Edzreena has been awarded as a Professional Technologist (Ts.) registered under the Malaysia Board of Technologists (MBOT) in 2018. She is also a certified professional in Requirement Engineering - Certified Professional Requirement Engineering Foundation Level (CPRE-FL) in 2018 and a certified Tester - Certified Testers Foundation Level (CTFL) in 2017. She specializes her research work in Software Risk Management, Software Process and Agile Methods however, her writing interest is span over in the broad Computer Science field.

Email: edzreena@utm.edu.my

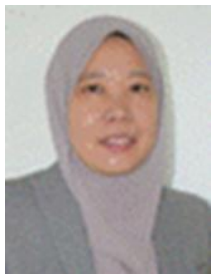

Noor Hasimah Ibrahim Teo is a Lecturer at the Universiti Teknologi MARA (UiTM) in Melaka, Malaysia. She holds a PhD in Computer Science fron university of Warwick, United Kingdom (2019), MSc in Computer Science from UiTM (2007). Her research interests center around computer science and education technology. Her current research is ontologies for automatic question generation. Email: shimateo@utm.edu.my 